experiments are all provided for. Individual microphones for the use of deaf persons can be connected to thirty seats, apart from the usual microphones used by the lecturer.

The Centre of Documentation aims not only at being a depository of all chemical knowledge, but also hopes to select, extract and arrange such knowledge in a manner that will render it most useful and most readily available to the individual investigator. It should be able to prepare fairly complete bibliographic information upon any chemical subject referred to it, supply photographic copies of the less easily available material, and translate matter from one language into another when necessary. It follows that the members of its staff will have to be highly trained, and many of them will need that particular flair that enables one to pick up from a large amount of material the essential facts that are likely to be useful in a given problem-by no means an easy undertaking, yet one which must be faced.

As regards equipment, the reading room provides at present for thirty readers, and is equipped with special optical and acoustical apparatus, since the library includes not only printed material but also films, gramophone records, etc. A glass partition separates the reading room from a smaller 'conversation' room, also provided with telephones.

The abstracting of scientific papers, patents and other documents and the compilation of bibliographies is carried out in the Ludwig Mond Hall, on the third floor of the building. This department can draw upon the bibliographical resources of many other organisations in addition to those of the Maison de la Chimie. This last is affiliated to the Union française des Organismes de Documentation, the task of which is to co-ordinate the great libraries of Paris:

The third section of the Maison de la Chimie is the Centre of Technical Improvement (Centre de Perfectionnement technique), which aims at keeping industrial chemists and others in contact with the latest developments in science. This it does by means of special courses of lectures and exhibitions. Several such series of lectures have already been arranged, dealing with new types of materials, the organisation of industry, etc.

The success which has attended the centralisation of chemical documentation and facilities in the Maison de la Chimie has opened even wider horizons. A "Cité des Sciences" is now being suggested, which would bring together all branches of science, act as a link between them, co-ordinate their discoveries and render them available to workers in every field, and strengthen the international bonds which bind together all those engaged in scientific work.

Many people have helped to bring about the successful completion of the Maison de la Chimie, but there can be no doubt that credit rests largely with its active administrateur, M. Jean Gérard, to whose vision and energy every one of those present at the inauguration paid a well-deserved tribute. M. Gérard has been for many years the secretary of the International Union of Chemistry, takes an active part in the editing of Chimie et Industrie and is president of the Union française des Organismes de Documentation (corresponding to ASLIB in Great Britain).

\title{
Large-Scale Plans of Great Britain
}

$\mathrm{I}^{\mathrm{T}}$ is a widely accepted fact that, since the War, the national large-scale plans of Great Britain have been getting more and more out of date. The reductions of staff, effected as a result of the recommendations of the Geddes Committee of 1922, have made it impossible for the Ordnance Survey to keep the plans in a reasonable state of repair. This is all the more to be regretted because the reductions in question only produced a trifling economy in the national budget. A leading article discussing the present position was published in NaTURE of November 3, and if, as we may hope, an inquiry is to be held into this matter, a recent publication by the Director of the Ordnance Survey* will provide a sure foundation of fact upon which it can be based.

* Ordnance Survey. Professional Papers, New Series, No. 16: The National Plans (The Ten-Foot, Five-Foot, Twenty-five-inch, and Six-inch Scales). By Brigadier H. St. J.' L. Winterbotham, Director-General of the Ordnance Survey 1934. Pp. $112+27$ plates. (London: H.M. Stationery Offiee, 1934.) 48. 6d. net.
A list of some of the headings of the sections of the report will serve to give an idea of its character. We find amongst these headings :- early British property surveys ; foreign analogies; city scales ; first revisions ; a pre-War stocktaking ; reductions [of staff]; co-ordinates and sheet lines; levels and bench marks; areas ; boundaries ; the name book ; air revision ; plans for registration; plans for land valuation; surveys for tithes, and other interesting matters.

Brigadier Winterbotham rightly says that, in the main, the history of the Ordnance Survey in the century before this year, that is, since 1834, remains to be written, and he remarks that the history of our large-scale plans is particularly vital. "The times are difficult. Short cuts and next bests suggest themselves in a variety of ways. It is time to take stock of where we are going."

Two generations ago, a commission of inquiry 
gave a list of seventeen purposes which come properly within the scope of a national survey, and to this number we may now add four more at least, namely, town and regional planning, the conveyance of property, land registration and land valuation. Here it is very appropriately pointed out that, chiefly as the result of Colby's foresight in 1825, it has always been the custom on the British large-scale plans to depict the actual physical features of the countryside on which the property boundaries depend, and not the boundaries themselves. "There seems to be no foreign analogy for the use in property questions of a map which shows no property boundaries as such. But then, in England, whether the actual boundary is coincident with the wall, fence or hedge, or not, the owner and his neighbours know at once from his enclosures what land he actually makes use of" . . " A purchaser going upon the property he is about to buy, with an accurate plan in his hand, can, in nine cases out of ten, identify the thing which he is buying with as much ease and certainty as if he had lived upon it all his life."

A good account is given of the city scales, namely, those of $1: 500$, often called the ten-foot scale, the $1: 528$, which is the true ten-foot scale, and the $1: 1056$ or five feet to the mile. These are beautiful and elaborate plans, executed on these various scales between 1843 and 1894, when they were discontinued by order of the Treasury, except in cases in which the local authority agrees to pay the extra cost involved as compared with the cost of the twenty-five inch plans. The last case of the kind was the Leeds survey of 1909-10, so that the arrangement nowadays is practically obsolete. For land registration, elsewhere than in London, enlargements of the $1: 2500$ to $1: 1250$ are used-not a perfect solution, but inexpensive.

The work contains much well-described technical matter, and will give an idea of the complexity of some of the problems dealt with. It may also serve to show that many of these problems have been discussed and examined at various times during the past century. But of course there are also new methods, and among these we may note the use of air photographs for large-scale revision. Various experiments have been made, chiefly with the view of seeing if economy would thereby result in the revision of the twenty-five inch plans. The question is not being allowed to drop, but it looks as if "town air revision may pay and country work certainly not". But much must depend upon the cost of the air photographs. The matter is not quite so straightforward as it might seem.

The report is well-illustrated. We find comparisons of the plans of twenty years ago and more with those of to-day. Examples are given of maps prepared for the Land Registry and of surveys for tithe redemption; and there are several interesting graphs which illustrate the amount of time spent on different classes of work. There is a useful chronology extending from 1820 to the present year. Indeed, anyone who desires to be correctly informed as to the many social and technical aspects of the national large-scale plans cannot do better than consult this work.

This is the first thorough account of the largescale plans of the Ordnance Survey that has ever been published, and many of those-and their name is legion-who use and appreciate these plans, will feel that they owe the present DirectorGeneral their hearty thanks for having placed this valuable history and description within their reach.

\section{Obituary}

Prof. Santiago Ramon-y-Cajal, for.mem.r.s. 7 HE microscopy of the nervous system had, by the latter half of last century, grown into something of a special study. It relied on its own votaries, not many but distributed world-wide. Fellowship in their somewhat recondite pursuit united them quasi-socially into a sort of family, a family not shrewdly discontent with its own achievement nor indeed gravely perturbed by a slowness of progress which seemed to challenge eternity. Upon this pedestrian tradition, when the century entered its final decade, burst suddenly an astonishing Spanish master. Santiago Ramon-y-Cajal of Valencia was then close on forty years of age. From the Pyrénnean slope, in a mountain village, where his father practised among the peasants, he had, when his parents moved, with their bare savings, to Zaragoza, been little of a success at school. So little in fact as to be twice withdrawn thence, once to assist a barber, and once again for apprenticeship to cobbling. He did cobbling well, but his father's ambition cherished the scalpel for him, though the boy's own pleading was for paintbrush and pencil. In after years indeed he substantiated his gift for draughtsmanship when his drawings became familiar to students the world over. Other recorded likings of the recalcitrant schoolboy were at that time the watching of birds and the reading of travels, and of these latter as prime favourite "Robinson Crusoe".

To anatomy, however, Santiago eventually settled down, under his father, its teacher at the University. Ramon senior was planning an anatomical atlas; for this, his son made drawings; but no publisher was found. Following medical study came military service, in Cuba, where he contracted malaria and tubercle. He returned after slow recovery to Zaragoza, this time as anatomical assistant. He secured his doctorate ; in 1884 he gained the chair of anatomy at Valencia. There in his house he installed a microscope and a tiny laboratory. He examined nerve 